in vivo $34: 2095-2100(2020)$

doi:10.21873/invivo.12013

\title{
Serum CEA and CYFRA Levels in ALK-rearranged NSCLC Patients: Correlation With Distant Metastasis
}

\author{
TAKESHI NUMATA ${ }^{1}$, TAKEO ENDO ${ }^{1}$, HIDETOSHI YANAI ${ }^{1}$, KYOKO OTA $^{1}$, YUSUKE YAMAMOTO ${ }^{2}$, \\ KEI SHIMIZU ${ }^{2}$, HIDEYASU YAMADA ${ }^{3}$, KENJI HAYASHIHARA ${ }^{4}$, SHINICHIRO OKAUCHI $^{5}$, HIROAKI SATOH $^{5}$, \\ YUTAKA YAMADA ${ }^{6}$, TOMOHIRO TAMURA ${ }^{6}$, KAZUTO SAITO $^{7}$, NORIHIRO KIKUCHI ${ }^{8}$, KOICHI KURISHIMA ${ }^{9}$, \\ HIROICHI ISHIKAWA ${ }^{9}$, HIROKO WATANABE ${ }^{10}$, TOSHIHIRO SHIOZAWA ${ }^{11}$, NOBUYUKI HIZAWA ${ }^{11}$, \\ YASUNORI FUNAYAMA ${ }^{12}$, SHIGEN HAYASHI ${ }^{13}$, HIROYUKI NAKAMURA ${ }^{14}$ and TAKAAKI YAMASHITA ${ }^{15}$ \\ ${ }^{1}$ Division of Respiratory Medicine, Mito Medical Center, Ibaraki-machi, Japan; \\ ${ }^{2}$ Division of Respiratory Medicine, Hitachi General Hospital, Hitachi, Japan; \\ ${ }^{3}$ Division of Respiratory Medicine, Hitachinaka Medical Center-Hitachinaka Medical Center, \\ University of Tsukuba, Hitachinaka, Japan; \\ ${ }^{4}$ Division of Respiratory Medicine, Ibarakihigashi Hospital, Tokai, Japan; \\ ${ }^{5}$ Division of Respiratory Medicine, Mito Kyodo General Hospital-Mito Medical Center, \\ University of Tsukuba, Mito, Japan; \\ ${ }^{6}$ Respiratory Center, Ibaraki Prefectural Central Hospital, Kasama, Japan; \\ ${ }^{7}$ Division of Respiratory Medicine, Tsuchiura Kyodo General Hospital, Tsuchiura, Japan; \\ ${ }^{8}$ Division of Respiratory Medicine, Kasumigaura Medical Center Hospital, Tsuchiura, Japan; \\ ${ }^{9}$ Division of Respiratory Medicine, Tsukuba Medical Center Hospital, Tsukuba, Japan; \\ ${ }^{10}$ Division of Thoracic Surgery, Tsukuba Kinen Hospital, Tsukuba, Japan; \\ ${ }^{11}$ Faculty of Clinical Medicine, University of Tsukuba, Tsukuba, Japan; \\ ${ }^{12}$ Division of Respiratory Medicine, Tsukuba Gakuen General Hospital, Tsukuba, Japan; \\ ${ }^{13}$ Division of Respiratory Medicine, Ibaraki Seinan Medical Center Hospital, Sakai-machi, Japan; \\ ${ }^{14}$ Division of Respiratory Medicine, Tokyo Medical University, Ibaraki Medical Center, Ami-machi, Japan; \\ ${ }^{15}$ Division of Respiratory Medicine, JA Toride Medical Center Hospital, Toride, Japan
}

\begin{abstract}
Aim: To clarify the correlation between serum levels of carcinoembryonic antigen (CEA) and cytokeratin 19 fragment (CYFRA) and metastasis and survival in anaplastic lymphoma kinase (ALK)-rearranged non-small cell lung cancer (NSCLC) patients. Patients and Methods: CEA and CYFRA levels in 131 ALK-rearranged NSCLC patients were determined using fluorescence in situ hybridization (FISH), real time-reverse transcription polymerase chain reaction, and immunohistochemistry, using
\end{abstract}

This article is freely accessible online.

Correspondence to: Hiroaki Satoh, MD, Ph.D., Division of Respiratory Medicine, Mito Medical Center, University of TsukubaMito Kyodo General Hospital, Miya-machi 3-2-7, Mito-city, Ibaraki, 310-0015, Japan. Tel: +81 292312371, Fax: +81 292215137,e-mail: hirosato@md.tsukuba.ac.jp

Key Words: Serum tumor markers, carcinoembryonic antigen, CEA, cytokeratin 19 fragment, CYFRA, ALK rearranged NSCLC, distant metastasis, non-small cell lung cancer. biopsy specimens, cytology specimens, and plasma specimens. Cut-off value of each marker was determined as $10 \mathrm{ng} / \mathrm{ml}$. Results: In logistic regression analysis, higher levels of both markers had a positive relationship with bone metastases, and higher levels of CYFRA was relevant to liver metastases, and multiple-organ metastases. However, these markers were not proven to be poor prognostic factors in Cox's proportional model analysis. Conclusion: Elevated serum CEA and CYFRA levels seem to provide useful clinical information about presence of bone and liver metastasis and multiple-organ metastases, although they were not a powerful indicator of prognosis. These two markers may suggest the extension of metastasis and would be helpful in considering treatment options.

Carcinoembryonic antigen (CEA) has been widely used in clinical practice as a serum tumor marker for non-small cell lung cancer (NSCLC) patients (1). Cytokeratin 19 fragment (CYFRA) is also one of the representative serum tumor markers used for detection of NSCLC patients in clinical practice (1). CEA is a glycoprotein and CYFRA is a soluble 
component of cytoskeleton cytokeratin (1). Although there is no tumor marker useful for the early diagnosis of NSCLC, there have been many reports that CEA and CYFRA reflect the extent of disease progression (1). Some of them have suggested that these tumor markers are unfavorable prognostic factors for NSCLC patients (1,2-4). The clinical problem has been that for both markers there exist several assay kits and cut-off values. Considering the accuracy of clinical information provided by current tumor markers for lung cancer, comparing values to the decimal point measured with different kits is of little clinical necessity. If the measured value is markedly high, the sample must be diluted and remeasured. At that time, the measurement error increases due to dilution. These backgrounds must be taken into account when evaluating serum levels of tumor markers for lung cancer. However, elevated serum levels may provide important information that can be used in clinical practice, even if they are at rough levels. It is worthwhile to fully understand the characteristics and measurement methods of each tumor marker and use them in clinical practice of NSCLC.

In the last two decades, advances in molecular biology have led to discovery of several specific driver genes in many cancers and development of specific therapeutic agents $(5,6)$. This new trend is also noticeable in clinical practice for NSCLC patients. Long-term survival can be expected in NSCLC patients with driver genes for which specific therapeutic agents exist $(5,6)$. Anaplastic lymphoma kinase (ALK) fusion gene mutation is one of such driver genes, but its frequency is very rare $(5,6)$. Because of the rarity of ALK-rearranged NSCLC, it is important to collect and evaluate data in clinical practice in addition to results from clinical trials. Recently, an interesting study pointed out that liver and bone invasion were unfavorable prognostic factors in patients with ALK-rearranged gene mutations (7).

Until now, we accumulated and published actual clinical data on lung cancer treatment collected by multiple medical Institutions covering the residents of the Ibaraki prefecture with a population of 3 million (8-11). In this study, we investigated the significance of serum levels of CEA and CYFRA in ALK-rearranged NSCLC patients in actual clinical practice, with special interest in distant metastasis and prognosis. Since it was possible to investigate information of ALK-rearranged NSCLC patients in over one hundred patients, we herein share our medical information in real clinical practice.

\section{Patients and Methods}

Patients. Fifteen institutions located in the Ibaraki prefecture (area, $6,095 \mathrm{~km}^{2}$; population, $\sim 3$ million) participated in the present retrospective study. We included patients who were diagnosed with ALK-rearranged NSCLC between April, 2008 and March, 2019. Treatment-naïve ALK-rearranged NSCLC patients whose serum CEA and CYFRA levels were measured at diagnosis were included
Table I. Characteristics of 113 ALK-rearranged NSCLC patients for whom measurement of serum levels of CEA and CYFRA were available.

\begin{tabular}{lc}
\hline Age (median, range), year & $63,32-84$ \\
Gender, M/F & $73 / 40$ \\
Histopathological type & \\
$\quad$ AD/SQ/NSCLC & $110 / 1 / 2$ \\
Performance status & \\
$\quad 0-1 / 2$ or more & $103 / 10$ \\
Smoking habit & \\
$\quad$ Never/past or current & $66 / 47$ \\
Pleural fluid & \\
$\quad$ Absent/present & $84 / 29$ \\
Bone metastasis & \\
$\quad$ Absent/present & $87 / 26$ \\
Liver metastasis & \\
$\quad$ Absent/present & $107 / 6$ \\
Number of metastatic sites & \\
$\quad 0-1 / 2$ or more & $80 / 33$ \\
Stage & \\
$\quad$ IA-B/IIA-B/IIIA-C/IVA-B & $20 / 9 / 24 / 25 / 50$ \\
Surgical resection & \\
$\quad$ Received/not received & $45 / 68$ \\
ALK-TKI therapy & \\
$\quad$ Received/not received & $76 / 37$ \\
Serum CEA level at the time of diagnosis & \\
$\quad \leq 10 \mathrm{ng} / \mathrm{ml} / \geq 10 \mathrm{n} / \mathrm{ml}$ & $72 / 41$ \\
Serum CYFRA level at the time of diagnosis & $100 / 3$ \\
$\quad \leq 10 \mathrm{ng} / \mathrm{ml} / \geq 10 \mathrm{n} / \mathrm{ml}$ & \\
\hline
\end{tabular}

ALK: Anaplastic lymphoma kinase; NSCLC: non-small cell lung cancer; CEA: carcinoembryonic antigen; CYFRA: cytokeratin 19 fragment; AD: adenocarcinoma; SQ: squamous cell carcinoma; NSCLC: non-small cell lung cancer; TKI: tyrosine kinase inhibitor.

in this study. NSCLC patients, who had any treatment before the approval of ALK fusion gene in 2012 and diagnosed as having the gene present, were included on this study. All the patients demonstrated histological or cytological evidence of NSCLC. Histopathological diagnoses were defined according to the World Health Organization (WHO) classification system and patients were staged according to the Union for International Cancer Control (UICC) tumor-node-metastasis (TNM) staging system. Metastatic sites were evaluated as bone, lung, brain, liver, extrathoracic lymph nodes, adrenal glands, and other uncommon sites. The clinical information of patient characteristics were evaluated using patient data extracted from the database of each Institution. Patient survival time was calculated from the date of initiation of first-line therapeutic drug to the date of death or last follow-up of the patient. The present observational study conformed to the Ethical Guidelines for Clinical Studies issued by the Ministry of Health, Labor and Welfare of Japan. This study was approved by the Institutional Review Board of the Mito Kyodo General Hospital (NO. 18-15) or independent Ethics Committees associated with each study Institute.

Measurement of ALK fusion gene, CEA, and CYFRA. ALK fusion gene mutation analysis was performed by the assay method normally used by each institution, such as fluorescence in situ hybridization (FISH), real time-reverse transcription polymerase chain reaction, and immunohistochemistry, using biopsy specimens, cytology specimens, 
Table II. Factors associated with bone metastasis in 113 ALKrearranged NSCLC patients.

\begin{tabular}{lccc}
\hline Factors & Exp. & $95 \%$ Confidence interval & $p$-Value \\
\hline $\begin{array}{l}\text { Age, less than 65, } \\
\text { 65 years or more }\end{array}$ & 0.479 & $0.158-1.453$ & 0.1934 \\
$\begin{array}{l}\text { Gender, M/F } \\
\text { Performance status } \\
\quad 0-1 / 2 \text { or more }\end{array}$ & 1.527 & $0.452-5.158$ & 0.4952 \\
$\begin{array}{l}\text { Smoking habit } \\
\quad \text { Never/past or current }\end{array}$ & 0.715 & $0.204-2.514$ & 0.6016 \\
$\begin{array}{l}\text { Pleural fluid } \\
\text { Absent/present }\end{array}$ & 1.212 & $0.351-4.182$ & 0.7607 \\
$\begin{array}{l}\text { CEA } \\
\quad \leq 10 \mathrm{ng} / \mathrm{ml} / \geq 10 \mathrm{n} / \mathrm{ml}\end{array}$ & 4.002 & $1.280-12.511$ & 0.0171 \\
$\begin{array}{l}\text { CYFRA } \\
\leq 10 \mathrm{ng} / \mathrm{ml} / \geq 10 \mathrm{n} / \mathrm{ml}\end{array}$ & 14.953 & $3.173-70.476$ & 0.0006 \\
\hline
\end{tabular}

ALK: Anaplastic lymphoma kinase; NSCLC: non-small cell lung cancer; Exp: exponential function; CEA: carcinoembryonic antigen; CYFRA: cytokeratin 19 fragment.
Table III. Factors associated with liver metastasis in 113 ALKrearranged NSCLC patients.

\begin{tabular}{|c|c|c|c|}
\hline Factors & Exp. & 95\% Confidence interval & $p$-Value \\
\hline $\begin{array}{l}\text { Age, less than } 65 \text {, } \\
65 \text { years or more }\end{array}$ & 2.742 & $0.350-21.482$ & 0.3369 \\
\hline Gender, M/F & 0.813 & $0.107-6.160$ & 0.8415 \\
\hline $\begin{array}{l}\text { Performance status } \\
0-1 / 2 \text { or more }\end{array}$ & 2.121 & $0.150-29.922$ & 0.5777 \\
\hline Smoking habit & & & \\
\hline $\begin{array}{l}\text { Never/past or current } \\
\text { Pleural fluid }\end{array}$ & 1.476 & $0.217-10.049$ & 0.6906 \\
\hline $\begin{array}{l}\text { Absent/present } \\
\text { CEA }\end{array}$ & 1.135 & $0.114-11.290$ & 0.9141 \\
\hline $\begin{array}{l}\leq 10 \mathrm{ng} / \mathrm{ml} / \geq 10 \mathrm{n} / \mathrm{ml} \\
\text { CYFRA }\end{array}$ & 0.510 & $0.057-4.587$ & 0.5480 \\
\hline$\leq 10 \mathrm{ng} / \mathrm{ml} / \geq 10 \mathrm{n} / \mathrm{ml}$ & 15.501 & $2.025-118.681$ & 0.0083 \\
\hline
\end{tabular}

ALK: Anaplastic lymphoma kinase; NSCLC: non-small cell lung cancer; Exp: exponential function; CEA: carcinoembryonic antigen; CYFRA: cytokeratin 19 fragment. and plasma specimens. Blood samples were collected within 2 weeks before the initial treatment, and serum CEA and CYFRA levels were measured by chemiluminescence immunoassays. Serum levels of CEA and CYFRA measured with commercial kits used in Japan's insurance medical practice were evaluated. In this study, we considered the cutoff values of CEA and CYFRA as $10 \mathrm{ng} / \mathrm{ml}$, as an easy-to-use measurement value in clinical practice.

Statistical analysis. The survival rate of patients was analyzed by the Kaplan-Meier method and comparisons were performed using the log-rank test. The effects of clinicopathological factors on survival were analyzed using the Cox proportional hazards model. $p<0.05$ was considered to indicate a statistically significant difference.

\section{Results}

Patient characteristics. During the study period, 129 patients were diagnosed as having ALK-rearranged NSCLC. Of the 129 patients, 113 NSCLC patients, who had both serum CEA and CYFRA measured at the time of diagnosis, were included in the study. Table I presents the characteristics of these patients. There were $40(35.4 \%)$ males and $73(64.6 \%)$ females. The median age was 63 (range $=32-84$ ) years, and $51(45.1 \%)$ patients were $\geq 65$ years old. FISH was the most common procedure to confirm ALK rearrangement. There were $103(91.1 \%)$ patients with a good performance status (PS) (Eastern Cooperative Oncology Group 0-1). Sixty-six $(58.4 \%)$ of them were no smokers. One hundred and ten (97.3\%) had adenocarcinoma.

Serum levels of CEA and CYFRA and metastasis. In this study, cut-off values for CEA and CYFRA were set at 10 $\mathrm{ng} / \mathrm{ml}$, taking into account the versatility of measurement levels in several assay kits commonly available in clinical practice. There were 41 patients who had serum CEA levels $\geq 10 \mathrm{ng} / \mathrm{ml}$. Thirteen patients had serum CYFRA levels $\geq 10$ $\mathrm{ng} / \mathrm{ml}$. Tables II, III, and IV show the results of logistic regression analysis in serum levels of CEA and CYFRA and metastasis. In this analysis, higher levels of both CEA and CYFRA had a relationship with bone metastases, and higher levels of CYFRA were relevant to liver metastases, and multiple-organ metastases.

Prognostic factors. In univariate analysis, 'poorer PS (2 or more)', 'positive smoking habit', 'no surgical resection', and 'elevated CEA levels $\geq 10 \mathrm{ng} / \mathrm{ml}$ ' were unfavorable prognostic factors. In Cox proportional hazards model analysis, however, none of these factors except for 'no surgical resection' were statistically significant unfavorable prognostic factors (Table V).

\section{Discussion}

ALK-rearranged NSCLC is a rare disease $(5,6)$. Unlike other clinical trials in NSCLC patients, phase III randomized controlled trials in ALK-rearranged NSCLC patients included up to 350 patients $(12,13)$. In most recent retrospective clinical practice studies, the number of patients evaluated was around 100 (14-20). Several studies on tumor markers in ALK-rearranged NSCLC patients have been reported (21-24). Many of these reports examined whether tumor markers could be useful for diagnosis (21-24). Also, the number of ALK-rearranged NSCLC patients studied was 
Table IV. Factors associated with multiple metastatic sites in $113 \mathrm{ALK}$ rearranged NSCLC patients.

\begin{tabular}{|c|c|c|c|}
\hline Factors & Exp. & 95\% Confidence interval & $p$-Value \\
\hline $\begin{array}{l}\text { Age, less than } 65 \text {, } \\
65 \text { years or more }\end{array}$ & 0.397 & $0.146-1.080$ & 0.0704 \\
\hline Gender, M/F & 0.975 & $0.330-2.881$ & 0.9637 \\
\hline $\begin{array}{l}\text { Performance status } \\
0-1 / 2 \text { or more }\end{array}$ & 1.607 & $0.332-8.034$ & 0.5632 \\
\hline $\begin{array}{l}\text { Smoking habit } \\
\text { Never/past or current }\end{array}$ & 2.065 & $0.696-6.130$ & 0.1914 \\
\hline $\begin{array}{l}\text { Pleural fluid } \\
\text { Absent/present }\end{array}$ & 3.244 & $1.110-9.479$ & 0.0314 \\
\hline $\begin{array}{l}\text { CEA } \\
\leq 10 \mathrm{ng} / \mathrm{ml} / \geq 10 \mathrm{n} / \mathrm{ml} \\
\text { CYFRA }\end{array}$ & 1.959 & $0.715-5.366$ & 0.1907 \\
\hline$\leq 10 \mathrm{ng} / \mathrm{ml} / \geq 10 \mathrm{n} / \mathrm{ml}$ & 8.050 & $1.746-37.127$ & 0.0075 \\
\hline
\end{tabular}

ALK: Anaplastic lymphoma kinase; NSCLC: non-small cell lung cancer; Exp: exponential function; CEA: carcinoembryonic antigen; CYFRA: cytokeratin 19 fragment.

low in many reports, up to 54 patients (21-24). In all NSCLC patients without considering gene mutations, there have been reports examining the significance of CEA and CYFRA in distant metastasis and prognosis. To our knowledge, however, there have been no reports investigating the association of serum levels of CEA and CYFRA with metastasis and prognosis in ALK-rearranged NSCLC patients. This was the first study to include more than 100 ALK-rearranged NSCLC patients. Regarding prognostic factors, several researchers are conducting studies in ALKrearranged NSCLC patients $(7,25-27)$. Among them, there was an interesting report from the research group of Jin et al. (7). According to their report, liver and bone invasions were significant unfavorable prognostic factors in ALKrearranged NSCLC patients (7). The results of this study were so interesting that we examined the relationship between liver and bone invasion and elevated serum levels of tumor markers in our patients. In this study, we considered the cutoff values of CEA and CYFRA cutoff values of CEA and CYFRA as $10 \mathrm{ng} / \mathrm{ml}$, as an easy-to-use measurement value in clinical practice. In the logistic regression analysis, the following three points became clear. First, patients with higher levels of both CEA and CYFRA were more likely to have bone metastases. Second, the higher-CYFRA group was more likely to have liver metastases. Third, the higherCYFRA group was more likely to have two or more metastatic sites. With regard to prognosis as shown by uniand multivariate analysis, the following two points were revealed: First, 'poorer PS (2 or more)', 'positive smoking habit', 'no surgical resection', and 'elevated CEA levels $\geq 10$ $\mathrm{ng} / \mathrm{ml}$ ' were unfavorable prognostic factors. Second, in Cox proportional hazards model analysis, however, none of these
Table V. Unfavorable prognostic factors 113 ALK-rearranged NSCLC patients.

\begin{tabular}{lcccc}
\hline Factors & $\begin{array}{c}\text { Logrank test } \\
p \text {-Value }\end{array}$ & \multicolumn{3}{c}{$\begin{array}{c}\text { Cox's proportional } \\
\text { hazard model }\end{array}$} \\
\cline { 3 - 5 } & & Exp & $\begin{array}{c}\text { 95\% Confidence } \\
\text { interval }\end{array}$ & $p$-Value \\
& & \multicolumn{3}{c}{} \\
\hline $\begin{array}{c}\text { Performance status } \\
\quad 0-1 / 2 \text { or more }\end{array}$ & 0.0234 & 1.706 & $0.637-4.570$ & 0.2880 \\
$\begin{array}{c}\text { Smoking habit } \\
\quad \text { Never/past or current }\end{array}$ & 0.0134 & 1.674 & $0.829-3.380$ & 0.1507 \\
$\begin{array}{c}\text { Surgical resection } \\
\quad \text { Absent/present }\end{array}$ & 0.0003 & 3.445 & $1.362-8.719$ & 0.0090 \\
$\begin{array}{c}\text { CEA } \\
\leq 10 \mathrm{ng} / \mathrm{ml} / \geq 10 \mathrm{n} / \mathrm{ml}\end{array}$ & 0.0301 & 1.431 & $0.704-2.908$ & 0.3221 \\
\hline
\end{tabular}

ALK: Anaplastic lymphoma kinase; NSCLC: non-small cell lung cancer; Exp: exponential function; CEA: carcinoembryonic antigen; CYFRA: cytokeratin 19 fragment.

factors except for 'no surgical resection' were statistically significant unfavorable prognostic factor. These results were considered clinically understandable. In other words, elevated serum CEA levels were interpreted as a result that suggested some clinical significance, but not a powerful indicator of prognosis.

There were several previous studies on the association between elevated serum levels of these markers and distant organ metastases (28-30). According to these reports, elevated levels of these markers might be considered an early warning sign in patients needing accurate imaging, as they are at higher risk of bone metastasis (28), liver metastasis (29), and several-organ metastases (30). Molecular biology studies show that CEA has a mechanism for distant organ metastasis via adhesive molecules (31). Sertić Milić and colleagues reported that the presence of soluble cytokeratin fragments in blood shed suggests a deviation from the primary site of the tumor (32). The results of these clinical and molecular biological studies and our results suggested that elevated serum levels of these markers could contribute to early detection of several-organ metastases including bone and liver metastases with careful imaging studies. This population-based, multi-institutional study covering a single prefecture has several limitations. Firstly, it was a retrospective study with patients from miscellaneous backgrounds. Secondly, the methods for examining ALKfusion gene mutations were not unified. Thirdly, the limited number of patients and the short period of investigation were also limitations. Fourthly, there have been several measurement kits in CEA and CYFRA, and these kits were used at different facilities. Therefore, the cutoff values of these markers had to be determined with priority on the 
usefulness in clinical practice. Fifth, the prognosis of ALKrearranged NSCLC patients studied was good, and there were few patients who died during the study period, therefore a detailed prognosis could not be examined. ALKrearranged NSCLC is a rare entity of NSCLC. Therefore, there may be "facts" regarding the treatment that cannot be grasped by clinical trials alone.

We do believe it is worthwhile to accumulate, collect and disclose clinical practice data to make these facts clear and we conducted this research based on this concept. ALKrearranged NSCLC patients who had elevated serum CEA and CYFRA at diagnosis (in this study serum levels $\geq 10 \mathrm{ng} / \mathrm{m}$ ) may have had bone, liver metastases, or distant metastases to several organs. This information may be useful for clinical practice, but verification in more patients is required.

\section{Conflicts of Interest}

The Authors do not have any conflicts of interest to disclose regarding this study.

\section{Authors' Contributions}

TN, TE, HS and NH designed the study. TN, TE, HY, KO, YY, KS, HY, KH, SO, HS, YY, TT, KS, RK, KK, HI, HW, TS, YF, SH, HN, and TY collected the data. TN, TE, SO, and HS analyzed the data and prepared the manuscript. All Authors approved the final version of the article.

\section{References}

1 Holdenrieder S, Wehnl B, Hettwer K, Simon K, Uhlig S and Dayyani F: Carcinoembryonic antigen and cytokeratin-19 fragments for assessment of therapy response in non-small cell lung cancer: a systematic review and meta-analysis. Br J Cancer 116(8): 1037-1045, 2017. PMID: 28278517. DOI: 10.1038/ bjc. 2017.45

2 Grunnet M and Sorensen JB: Carcinoembryonic antigen (CEA) as tumor marker in lung cancer. Lung Cancer 76(2): 138-143, 2012. PMID: 22153832. DOI: 10.1016/j.lungcan.2011.11.012

3 Ishikawa H, Satoh H, Yamashita YT, Ohtsuka M and Sekizawa $\mathrm{K}$ : CEA and survival in patients with stage IA-B NSCLC. Thorac Cardiovasc Surg 50(4): 253, 2002. PMID: 12165878. DOI: $10.1055 / \mathrm{s}-2002-33098$

4 Suzuki H, Ishikawa S, Satoh H, Ishikawa H, Sakai M, Yamamoto T, Onizuka M and Sakakibara Y: Preoperative CYFRA 21-1 levels as a prognostic factor in c-stage I non-small cell lung cancer. Eur J Cardiothorac Surg 32(4): 648-652, 2007. PMID: 17707649. DOI: 10.1016/j.ejcts.2007.06.032

5 Bronte G, Rizzo S, La Paglia L, Adamo V, Siragusa S, Ficorella C, Santini D, Bazan V, Colucci G, Gebbia N and Russo A: Driver mutations and differential sensitivity to targeted therapies: a new approach to the treatment of lung adenocarcinoma. Cancer Treat Rev 36 Suppl 3: S21-29, 2010. PMID: 21129606. DOI: 10.1016/S0305-7372(10)70016-5

6 Hallberg B and Palmer RH: Mechanistic insight into ALK receptor tyrosine kinase in human cancer biology. Nat Rev
Cancer 13(10): 685-700, 2013. PMID: 24060861. DOI: $10.1038 / \mathrm{nrc3580}$

7 Jin Y, Chen Y, Yu X and Shi X: A real-world study of treatment patterns and survival outcome in advanced anaplastic lymphoma kinase-positive non-small-cell lung cancer. Oncol Lett 15(6): 8703-8710, 2018. PMID: 29805608. DOI: 10.3892/ol.2018.8444

8 Nakamura H, Satoh H, Kaburagi T, Nishimura Y, Shinohara Y, Inagaki $M$, Endo $T$, Saito $T$, Hayashihara $K$, Hizawa $N$, Kurishima K, Nawa T, Kagohashi K, Kishi K, Ishikawa H, Ichimura H, Hashimoto T, Sato Y, Sakai M, Kamiyama K, Matsumura $\mathrm{T}$, Unoura $\mathrm{K}$ and Furukawa $\mathrm{K}$ : Bevacizumabcontaining chemotherapy for non-small cell lung cancer patients: a population-based observational study by the Ibaraki thoracic integrative (POSITIVE) research group. Med Oncol 29(5): 32023206. PMID: 23117478. DOI: 10.1007/s12032-012-0318-5

9 Hayashibara K, Satoh H, Shinohara Y, Inagaki M, Kaburagi T, Hashimoto T, Kurishima K, Ishikawa H, Ichimura H, Nawa T, Funayama Y, Matsumura T, Kagohashi K, Endo T, Furukawa K, Kishi K, Sumi M, Kamiyama K and Ishikawa S: A populationbased study of gefitinib in patients with non-small cell lung cancer. Med Oncol 26(2): 222-227, 2009. PMID: 18975151. DOI: $10.1007 / \mathrm{s} 12032-008-9110-\mathrm{y}$

10 Kaburagi T, Satoh H, Hayashihara K, Endo T, Hizawa N, Kurishima K, Nishimura Y, Hashimoto T, Nakamura H, Kishi K, Inagaki M, Nawa T, Ichimura H, Ishikawa H, Kagohashi K, Fukuoka T, Shinohara Y, Kamiyama K, Sato Y, Sakai M, Matsumura T, Uchiumi K and Furukawa K: Observational study on the efficacy and safety of erlotinib in patients with non-small cell lung cancer. Oncol Lett 5(2): 435-439, 2013. PMID: 23420613. DOI: $10.3892 / 01.2012 .1048$

11 Miyazaki K, Tamura T, Kaburagi T, Saito K, Inagaki M, Yamashita T, Ichimura H, Nawa T, Endo T, Hayashihara K, Kimura M, Kurishima K, Nakamura H, Furukawa K, Kikuchi N, Satoh $\mathrm{H}$ and Hizawa N: Real clinical practice of using afatinib therapy in NSCLC patients with an acquired EGFR T790M mutation. Anticancer Res 38(9): 5409-5415, 2018. PMID: 30194196. DOI: 10.21873 /anticanres.12871

12 Solomon BJ, Mok T, Kim DW, Wu YL, Nakagawa K, Mekhail T, Felip E, Cappuzzo F, Paolini J, Usari T, Iyer S, Reisman A, Wilner KD, Tursi J and Blackhall F; PROFILE 1014 Investigators: First-line crizotinib versus chemotherapy in ALKpositive lung cancer. N Engl J Med 371(23): 2167-2177, 2014. PMID: 25470694. DOI: 10.1056/NEJMoa1408440

13 Peters S, Camidge DR, Shaw AT, Gadgeel S, Ahn JS, Kim DW, Ou SI, Pérol M, Dziadziuszko R, Rosell R, Zeaiter A, Mitry E, Golding S, Balas B, Noe J, Morcos PN and Mok T; ALEX Trial Investigators: Alectinib versus crizotinib in untreated ALK-positive non-small-cell lung cancer. N Engl J Med 377(9): 829-838, 2017. PMID: 28586279. DOI: 10.1056/ NEJMoa1704795

14 Pacheco JM, Gao D, Smith D, Purcell T, Hancock M, Bunn P, Robin T, Liu A, Karam S, Gaspar L, Kavanagh B, Rusthoven C, Aisner D, Doebele R and Camidge DR: Natural history and factors associated with overall survival in stage IV ALKrearranged non-small cell lung cancer. J Thorac Oncol 14(4): 691700, 2019. PMID: 30599201. DOI: 10.1016/j.jtho.2018.12.014

15 Gainor JF, Tan DS, De Pas T, Solomon BJ, Ahmad A, Lazzari C, de Marinis F, Spitaleri G, Schultz K, Friboulet L, Yeap BY, Engelman JA and Shaw AT: Progression-free and overall survival in ALK-positive NSCLC patients treated with sequential 
crizotinib and ceritinib. Clin Cancer Res 21(12): 2745-2752, 2015. PMID: 25724526. DOI: 10.1158/1078-0432

16 Ito $\mathrm{K}$, Hataji $\mathrm{O}$, Kobayashi $\mathrm{H}$, Fujiwara A, Yoshida M, D'Alessandro-Gabazza CN, Itani H, Tanigawa M, Ikeda T, Fujiwara K, Fujimoto H, Kobayashi T, Gabazza EC, Taguchi O and Yamamoto N: Sequential therapy with crizotinib and alectinib in ALK-rearranged non-small cell lung cancer-A multicenter retrospective study. J Thorac Oncol 12(2): 390-396, 2017. PMID: 27498387. DOI: 10.1016/j.jtho.2016.07.022

17 Kayaniyil S, Hurry M, Wilson J, Wheatley-Price P, Melosky B, Rothenstein J, Cohen V, Koch C, Zhang J, Osenenko K and Liu G: Treatment patterns and survival in patients with ALK-positive non-small-cell lung cancer: a Canadian retrospective study. Curr Oncol 23(6): e589-e597, 2016. PMID: 28050149. DOI: $10.3747 / \operatorname{co} .23 .3273$

18 Martín C, Cardona AF, Zatarain-Barrón ZL, Ruiz-Patiño A, Castillo O, Oblitas G, Corrales L, Lupinacci L, Pérez MA, Rojas L, González L, Chirinos L, Ortíz C, Lema M, Vargas C, Puparelli C, Carranza H, Otero J and Arrieta O: Real-world treatment patterns, survival, and prediction of CNS progression in ALK-positive non-small-cell lung cancer patients treated with first-line crizotinib in latin america oncology practices. Oncology 94(5): 297-305, 2018. PMID: 29510386. DOI: $10.1159 / 000486862$

19 Bedas A, Peled N, Maimon Rabinovich N, Mishaeli M, Shochat T, Zer A, Rotem O, Allen AM, Bar J and Dudnik E; On behalf of the Israel Lung Cancer Group: Efficacy and safety of ALK tyrosine kinase inhibitors in elderly patients with advanced ALK-positive non-small cell lung cancer: findings from the reallife cohort. Oncol Res Treat 42(5): 275-282, 2019. PMID: 30955009. DOI: 10.1159/000499086

20 Descourt R, Perol M, Rousseau-Bussac G, Planchard D, Mennecier B, Wislez M, Cortot A, Guisier F, Galland L, Dô P, Schott R, Dansin E, Arrondeau J, Auliac JB and Chouaid C: Brigatinib in patients with ALK-positive advanced non-smallcell lung cancer pretreated with sequential ALK inhibitors: A multicentric real-world study (BRIGALK study). Lung Cancer 136: 109-114, 2019. PMID: 31491676. DOI: 10.1016/j.lungcan. 2019.08.010

21 Wang S, Ma P, Ma G, Lv Z, Wu F, Guo M, Li Y, Tan Q, Song S, Zhou E, Geng W, Duan Y, Li Y and Jin Y: Value of serum tumor markers for predicting EGFR mutations and positive ALK expression in 1089 Chinese non-small-cell lung cancer patients: A retrospective analysis. Eur J Cancer 124: 1-14, 2020. PMID: 31707279. DOI: 10.1016/j.ejca.2019.10.005

22 Tan Q, Huang Q, Ma G, Lv Z, Mei P, Mao K, Wu F and Jin Y: Relationship between serum tumor markers and Anaplastic Lymphoma Kinase mutations in stage IV lung adenocarcinoma in Hubei province, Central China. J Clin Lab Anal 34(1): e23027, 2020. PMID: 31489711. DOI: 10.1002/jcla.23027

23 Wang $\mathrm{Z}$, Yang $\mathrm{S}$ and $\mathrm{Lu} \mathrm{H}$ : Preoperative serum carcinoembryonic antigen levels are associated with histologic subtype, EGFR mutations, and ALK fusion in patients with completely resected lung adenocarcinoma. Onco Targets Ther 10: 3345-3351, 2017. PMID: 28744138. DOI: 10.2147/ OTT.S134452
24 Wang WT, Li Y, Ma J, Chen XB and Qin JJ: Serum carcinoembryonic antigen levels before initial treatment are associated with EGFR mutations and EML4- ALK fusion gene in lung adenocarcinoma patients. Asian Pac J Cancer Prev 15(9): 3927-3932, 2014. PMID: 24935562. DOI: 10.7314/apjcp. 2014.15.9.3927

25 Saito S, Espinoza-Mercado F, Liu H, Sata N, Cui X and Soukiasian HJ: Current status of research and treatment for nonsmall cell lung cancer in never-smoking females. Cancer Biol Ther 18(6): 359-368, 2017. PMID: 28494184. DOI: 10.1080/ 15384047.2017 .1323580

26 Okauchi S, Numata T, Nawa T, Ichimura H, Saito T, Hayashihara K, Yamada H, Satoh H, Endo T, Inage Y, Kaburagi T, Kiyoshima M, Yamada Y, Tamura T, Saito K, Inagaki M, Hizawa N, Sato Y, Shiozawa T, Sekine I, Ishikawa H, Kurihima K, Sakai M, Kamiyama K, Kimura M, Kikuchi N, Nakamura H, Furukawa K, Kodama T, Miyazaki K, Yamashita T, Hayashi S, Funayama $\mathrm{Y}$ and Nomura A: Real clinical practice in ALKrearranged NSCLC patients: a retrospective observational study. Anticancer Res 40(2): 957-964, 2020. PMID: 32014940. DOI: 10.21873/anticanres.14029

27 Liu Y, Ye X, Yu Y and Lu S: Prognostic significance of anaplastic lymphoma kinase rearrangement in patients with completely resected lung adenocarcinoma. J Thorac Dis 11(10): 4258-4270, 2019. PMID: 31737311. DOI: $10.21037 /$ jtd. 2019.09.65

28 Ayan AK, Erdemci B, Orsal E, Bayraktutan Z, Akpinar E, Topcu A, Turkeli M and Seven B: Is there any correlation between levels of serum ostepontin, CEA, and FDG uptake in lung cancer patients with bone metastasis? Rev Esp Med Nucl Imagen Mol 35(2): 102-106, 2016. PMID: 26521996. DOI: 10.1016/ j.remn.2015.09.002

29 Kawahara H, Yoshida S, Tohyama Y, Yanagisawa S, Misawa T and Yanaga K: Serum carcinoembryonic antigen levels before the first curative hepatectomy for metastatic colorectal cancer is a predictor of recurrence. Anticancer Res 38(9): 5351-5355, 2018. PMID: 30194188. DOI: 10.21873/anticanres.12863

30 Pujol JL, Boher JM, Grenier J and Quantin X: Cyfra 21-1, neuron specific enolase and prognosis of non-small cell lung cancer: prospective study in 621 patients. Lung Cancer 31(2-3): 221-231, 2001. PMID: 11165401. DOI: 10.1016/s01695002(00)00186-0

31 Abdul-Wahid A, Huang EH, Cydzik M, Bolewska-Pedyczak E and Gariépy $\mathrm{J}$ : The carcinoembryonic antigen IgV-like $\mathrm{N}$ domain plays a critical role in the implantation of metastatic tumor cells. Mol Oncol 8(2): 337-350, 2014. PMID: 24388361. DOI: 10.1016/j.molonc.2013.12.002

32 Sertić Milić H, Franjević A, Bubanović G, Marušić A, Nikolić I and Puljić I: Size, edge, and stage of NSCLC determine the release of CYFRA 21-1 in bloodstream. Wien Klin Wochenschr 127(11-12): 465-471, 2015. PMID: 25917364. DOI: 10.1007/ s00508-014-0678-2

Received March 10, 2020

Revised March 31, 2020

Accepted April 1, 2020 